\title{
PENGARUH PEMBERIAN D-GALAKTOSA TERHADAP BERAT BADAN MENCIT BETINA
}

\author{
Novrina Situmorang \\ Departemen Anatomi Fakultas Kedokteran Universitas Methodist Indonesia, Medan, Indonesia \\ Email: novrinasitumorang@ymail.com
}

DOI: https://doi.org/10.46880/methoda.Vol11No2.pp133-137

\begin{abstract}
Experimental animals are animals that are developed so that they can be used as model animals in an experiment for the development of various fields of science, especially in the field of medical science. Aging is the accumulation of various changes that occur in cells and tissues that along with increasing age, pose a risk of disease and death. One of the signs of aging is weight gain. Aging can occur more quickly, this is due to various factors. One of them is the free radical factor. Administration of d-galactose can induce generalized aging of various organ systems. Administration of d-galactose for 6 weeks in a row causes an increase in galactose in the body. Giving d-galactose to mice will cause oxidative stress that will cause aging. So that the increase in body weight of mice as a sign of aging needs to be studied. The study was conducted in the pharmacology laboratory of the Faculty of Medicine, University of North Sumatra with a total sample of 6 female mice with an average body weight of 20-35 grams. Mice were injected with d-galactoa as much as 150 $\mathrm{mg} / \mathrm{kgBW}$ once every day for 6 weeks. Mice were weighed weekly for 6 weeks. The results of the study mice experienced a significant increase in body weight $p$ value $<0.005$. This happened because the continuous administration of d-galactose resulted in the accumulation of galactose in the tissue of female mice.
\end{abstract}

Keyword: D-Galactose, Mice, Aging.

\begin{abstract}
ABSTRAK
Hewan coba merupakan hewan yang sengaja dikembangkan agar dapat digunakan sebagai hewan model dalam suatu percobaaan untuk pengembangan berbagai bidang ilmu terutama dalam bidang ilmu kedokteran. Penuaan merupakan akumulasi berbagai perubahaan yang terjadi di dalam sel dan jaringan yang seiring dengan penambahan usia, menimbulkan risiko penyakit dan kematian. Salah satu tanda munculnya penuaan adalah peningkatan berat badan. Penuaan dapat terjadi lebih cepat, hal ini disebabkan oleh berbagai faktor. Salah satu diantaranya adalah faktor radikal bebas. Pemberian d-galaktosa dapat menginduksi penuaan menyeluruh pada berbagai sistem organ. Pemberian d-galaktosa selama 6 minggu berturut-turut menyebabkan peningkatan galaktosa dalam tubuh. Pemberian d-galaktosa pada mencit akan menyebabkan stress oksidatif sehingga akan menyebabkan penuaan. Sehingga peningkatan berat badan mencit sebagai suatu tanda dari penuaan perlu dikaji. Penelitian dilaksanakan di laboratorium farmakologi Fakultas Kedokteran Universitas Sumatera Utara dengan jumlah sampel sebanyak 6 ekor mencit betina dengan berat badan rata-rata 20-35 gram. Mencit diinjeksi d-galaktoa sebanyak 150 $\mathrm{mg} / \mathrm{kgBB}$ sebanyak 1 kali setiap hari selama 6 minggu. Mencit ditimbang setiap minggu selama 6 minggu. Hasil penelitian mencit mengalami peningkatan berat badan yang bermakna nilai $\mathrm{p}<0.005$. Hal ini terjadi karena pemberian d-galaktosa secara terus menerus mengakibatkan terakumulasinya galaktosa dalam jaringan mencit betina.
\end{abstract}

Kata Kunci: D-Galactosa, Mencit, Penuaan. 


\section{PENDAHULUAN}

Hewan percobaan biasanya digunakan dalam penelitian kesehatan untuk menguji kelayakan dan keamanan suatu obat dan juga dalam penelitian suatu penyakit. Hewan coba merupakan hewan yang sengaja dikembangkan agar dapat digunakan sebagai hewan model dalam suatu percobaaan untuk pengembangan berbagai bidang ilmu terutama dalam bidang ilmu kedokteran. Hewan coba yang banyak digunakan adalah mencit (Mus musculus), tikus putih (Rattus Norvegicus),kelinci (Oryctolagus cuniculus), dan hamster(Tolistiawaty, Widjaja, Sumolang, \& Octaviani, 2015).

Semua orang secara alami akan mengalami proses penuaan. Penuaan merupakan akumulasi berbagai perubahaan yang terjadi di dalam sel dan jaringan yang seiring dengan penambahan usia, menimbulkan risiko penyakit dan kematian (Sergiev, Dontsova, \& Berezkin, 2015). Proses penuaan akan berlangsung dari sejak lahir dan akan berakhir dengan kematian. Adanya penuaan dapat dilihat dari munculnya rambut beruban, perubahan elastisitas kulit, kemunduran daya ingat, adanya kecacatan secara fungsional. (Amarya, Singh, \& Sabharwal, 2016).

Peningkatan berat badan juga menjadi salah satu pertanda penuaan (He et al., 2020). Faktor penyebab penuaan dini meliputi faktor internal dan eksternal. Faktor internal terdiri dari faktor genetic (Tosato, Zamboni, Ferrini, \& Cesari, 2007), hormon (Diloreto, Murphy, \& Bement, 2013), stress (Liochev \& Court, 2015), dan ras (Huang, 2017). Faktor internal tidak bisa dihindari karena ia berlangsung secara alamiah pada manusia (Sgarbieri, Teresa, \& Pacheco, 2017). Faktor eksternal antara lain adalah sinar matahari, merokok, mengkonsumsi minuman alkohol berlebihan, pola makan yang buruk, dan radikal bebas (Sgarbieri et al., 2017). Menurut Gladysev radikal bebas merupakan reaksi utama proses penuaan, teori ini juga mengemukakan bahwa usia hidup ditentukan oleh tingkat kerusakan mitokondria oleh radikal bebas. Peningkatan stres oksidatif-terkait usia terjadi akibat ketidakseimbansgan produksi radikal bebas dan antioksidan (Gladyshev, 2013).
Reactive oxygen species (ROS) bersifat sangat reaktif dan merupakan oksidator kuat yang mampu berikatan dengan molekul disekitarnya. Dengan demikian, ROS dapat merusak sel dengan mengoksidasi hampir semua biomolekul termasuk protein, DNA nukleus dan mitokondria, lipid dan karbohidrat (Handy \& Loscalzo, 2012). ROS yang berlebihan akan menginduksi kerusakan komponen seluler secara permanen dan memicu kematian sel melalui jalur apoptosis intrinsik (mitokondria) dengan memicu kerusakan dan disfungsi DNA mitokondria.

Pemberian d-galaktosa dapat menginduksi penuaan menyeluruh pada berbagai sistem organ (Ji et al., 2017). Pemberian d-galaktosa selama 6 minggu berturut-turut menyebabkan peningkatan galaktosa dalam tubuh (Ahangarpour et al., 2014). Selanjutnya, aldosa reduktase mengubah galaktosa menjadi galaktitol, satu senyawa yang tidak dapat dimetabolisme oleh tubuh. Akumulasi galaktitol dalam sel menyebabkan perubahan tekanan osmotik, pembengkakan sel, disfungsi sel, dan penuaan (Ye, Jia, Tang, \& Chen, 2014). Mekanisme ini mendorong pembuatan banyak hewan coba model penuaan menggunakan dgalaktosa (Sulistyoningrum \& Article, 2016). Induksi d-galaktosa menyebabkan stress oksidatif pada berbagai jaringan melalui peningkatan produksi ROS dan advanced glycation endproduct seperti layaknya terjadi pada penuaan alamiah (Mohammadi, Mehri, Bostan, \& Hosseinzadeh, 2018).

Pemberian d-galaktosa pada mencit akan menyebabkan stress oksidatif sehingga akan menyebabkan penuaan. Sehngga penngkatan berat badan mencit sebagai suatu tanda dari penuaan perlu dikaji.

\section{METODE}

Penelitian ini adalah penelitian eksperimental in vivo dengan desain penelitian post test -only control group (Budiarto, 2001). Penelitian dilaksanakan di Laboratorium Farmakologi, Fakultas Kedokteran Universitas Sumatera Utara (FK USU) untuk pemeliharaan mencit model penuaan dan perlakuan terhadap hewan 
model. Sampel dalam penelitian ini adalah mencit betina sebanyak 6 ekor yang berumur 1012 minggu dan berat badan 20-35 g dengan kriteria inklusi diantaranya dalam keadaan tidak atau belum pernah hamil, berasal dari tempat pembiakan yang sama, dipelihara pada tempat dan waktu yang sama, belum pernah digunakan sebagai bahan penelitian. Sedangkan kriteria eksklusinya adalah semua mencit betina yang tampak sakit selama proses pemeliharaan ditentukan dengan gerak terbatas bulu terlihat kusam atau terdapat luka/bekas luka gigitan.

Hewan mencit direkayasa menjadi hewan coba model penuaan dengan suntikan intra peritoneal d-galaktosaberdosis $150 \mathrm{mg} / \mathrm{kgBB}$ selama 6 minggu (Sulistiyoningrum, 2017; Ji et al., 2017; Sadigh-Eteghad et al., 2017).

Data penelitian dianilisis menggunakan perangkat lunak statistik. Penelitian ini sudah mendapatkan persetujuan etik dari Komite Etik Penelitian FMIPA USU Medan. Mencit diaklimatisasi terlebih dahulu selama 1 minggu, ditempatkan dalam kandang yang sudah dialasi sekam, ditempatkan didalam ruang dengan lampu pencahayaan selama 12 jam dan berpengatur suhu ruangan. Kandang dibersihkan dan sekam diganti setiap minggu.

Alat dan Bahan yang dibutuhkan dalam penelitian ini adalah: kandang mencit, kawat jaring, sarung tangan, timbangan, gelas beaker, spuit $1 \mathrm{~mL}$, masker, lampu. Bahan- bahan yang digunakan yaitu D-galaktosa (merk galactose anhydrous) dan aquades.

Proses kerja: Sebelum diinjeksi dengan Dgalaktosa mencit terlebih dahulu ditimbang berat badannya. Setelah selesai ditimbang berat badan mencit kemudian, mencit diinjeksi dengan Dgalaktosa $150 \mathrm{mg} / \mathrm{kgBB}$ sebanyak 1 kali setiap hari. Dosis d-galaktosa disesuaikan dengan berat badan awal saat ditimbang. Mencit ditimbang setiap minggu selama 6 minggu.

\section{HASIL DAN PEMBAHASAN}

Penelitian ini mendapati berat badan mencit meningkat selama pemeliharaan 6 minggu. Dengan demikian dapat dikatakan bahwa mencit berada dalam keadaan sejahtera selama pemeliharaan dan memuhi syarat-syarat pemeliharaan hewan coba selama penelitian.
Hasil penelitian dapat dilihat pada tabel 1 berikut:

Tabel 1. Berat bedan mencit betina sebelum dan sesudah perlakuan

\begin{tabular}{|l|l|l|}
\hline \multicolumn{2}{|l|}{$\begin{array}{l}\text { Berat Badan Mencit } \\
\text { (mean } \pm \text { SD) }\end{array}$} & p \\
\cline { 1 - 2 } $\begin{array}{l}\text { Sebelum Perlakuan } \\
\text { (Minggu 0 (gr)) }\end{array}$ & $26,83 \pm 1,72$ & $<0.001$ \\
\cline { 1 - 2 } $\begin{array}{l}\text { Setelah Perlakuan } \\
\text { (Minggu 6 (gr)) }\end{array}$ & $33,50 \pm 1,87$ & \\
\hline
\end{tabular}

Ket: Data disajikan dalam mean \pm SD. Nilai $p$ dianggap bermakna bila $\mathrm{p}<0,05$.

Dari hasil uji Mann-Whitney dapat dilihat adanya perbedaan berat badan mencit betina sebelum dan sesudah perlakuan yang bermakna $(\mathrm{p}<0.05)$.

Penelitian ini mendapati berat badan mencit meningkat selama pemeliharaan 6 minggu. Dengan demikian dapat dikatakan bahwa mencit berada dalam keadaan sejahtera selama pemeliharaan dan memuhi syarat-syarat pemeliharaan hewan coba selama penelitian. Syarat-syarat pemeliharaan hewan coba selama penelitian ditentukan sebagai berikut:

1. Fasilitas kandang dimana hewan dipelihara harus ada staf, dirancang, dibangun, dilengkapi dan dipelihara dengan sesuai untuk mencapai standard dari pemeliharaan hewan yang tinggi dan harus memenuhi persyaratan ilmiah.

2. Secara umum, praktek pemeliharaan dan pengaturan harus dirancang untuk menyediakan suatu standard pemeliharaan yang tinggi dan harus mengikuti standard kesejahteraan hewan yang dapat diterima untuk species tertentu yang dilindungi. Dalam menentukan standard pemeliharaan hewan, kriterianya harus memperhatikan kesejahteraan hewan dibandingkan dengan kemampuan hewan untuk sekedar bertahan hidup dibawah kondisi yang buruk seperti lingkungan yang ekstrim atau jumlah populasi yang tinggi.

3. Standard untuk perawatan hewan harus dipelihara selama akhir pekan atau libur .

4. Prosedur perawatan darurat harus tersedia setiap saat. (ITB, 2014) 
Seluruh mencit mengalami kenaikan berat badan yang signifikan $(p<0,05)$. Kenaikan berat badan ini terjadi karena adanya pertambahan usia (Mardiati \& Sitasiwi, 2016). Pemberian dgalaktosa $150 \mathrm{mg} / \mathrm{kgbb}$ pada penelitian ini bertujuan untuk induksi penuaan. Pemberian dgalaktosa secara terus menerus mengakibatkan terakumulasinya galaktosa dalam jaringan mencit betina.

D-galaktosa adalah aldohexose yang terjadi secara alami di tubuh, termasuk di otak. Namun, ketika dosis D-galaktosa diberikan melebihi dosis normal $(10 \mathrm{mg} / \mathrm{dL})$ ini dapat menginduksi efek penuaan di beberapa organ yang dapat meningkatkan stress oksidatif (Shwe et al., 2018).

Menurut penelitian Zhao et al., 2018 terjadi kenaikan berat badan pada mencit yang diberikan Dgalaktosa yang diberikan selama 8 minggu. Sama dengan penelitian sebelumnya Chen et al., 2019 pada mencit yang diberikan Dgalaktosa sebanyak $150 \mathrm{mg} / \mathrm{kg} / \mathrm{bb}$ selama 8 minggu terjadi kenaikan berat badan.

\section{KESIMPULAN}

Sampel yang digunakan dalam penelitian ini adalah 6 sampel dengan berat badan $25-35$ gram sebelum diberikan perlakuan. Tidak terdapat peningkatan berat badan yang bermakna pada saat sebelum perlakuan dan setelah perlakuan.

\section{DAFTAR PUSTAKA}

Ahangarpour, A., Heidari, H., Ali, R., Fatemeh, A., Pakmehr, M., \& Shahbazian, H. (2014). Effect of Boswellia serrata supplementation on blood lipid, hepatic enzymes and fructosamine levels in type 2 diabetic patients. Journal of Diabetes and Metabolic Disorder, 8, 1-5.

Amarya, S., Singh, K., \& Sabharwal, M. (2016). Ageing Process and Physiological Changes. In Intech.

Budiarto. (2001). Biostatistika untuk kedokteran dan kesehatan masyarakat. EGC.

Diloreto, R., Murphy, C. T., \& Bement, W. (2013). The cell biology of aging. In Department of Molecular Biology (Vol. 08544, pp. 4524-4531).
Gladyshev, V. N. (2013). The Free Radical Theory of Aging Is Dead. Long Live the Damage Theory! Antioxidants \& Redox Signaling, 20(4), 727-731.

Handy, D. E., \& Loscalzo, J. (2012). Redox Regulation of Mitochondrial Function. 16(11).

He, X., Tian, Y., Lei, L., Zhi, Q., Zhao, J., \& Ming, J. (2020). Protective effects of Coreopsis tinctoria buds extract against cognitive impairment and brain aging induced by D-galactose. Journal of Functional Foods, 73(March), 104089. https://doi.org/10.1016/j.jff.2020.104089

Huang, A. D. S. Z. X. (2017). Current Perspective in the Discovery of Anti-aging Agents from Natural Products. Natural Products and Bioprospecting, 7(5), 335404. https://doi.org/10.1007/s13659-0170135-9

ITB. (2014). Guidelines On Animal Care And Use For Education School of Life Sciences and Technology Institut Teknologi Bandung. Bandung.

Ji, M., Su, X., Liu, J., Zhao, Y., Li, Z., Xu, X., ... Nashun, B. (2017). Comparison of naturally aging and D-galactose induced aging model in beagle dogs. Experimental and Therapeutic Medicine, 14(6), 58815888.

Liochev, S. I., \& Court, F. (2015). Which Is the Most Significant Cause of Aging. Antioxidants, 4, 793-810.

Mardiati, S. M., \& Sitasiwi, A. J. (2016). Pertambahan Berat Badan Mencit (Mus musculus L.) Setelah Perlakuan Ekstrak Air Biji Pepaya (Carica papaya Linn .) Secara Oral Selama 21 Hari. 1, 1-6.

Mohammadi, E., Mehri, S., Bostan, H. B., \& Hosseinzadeh, H. (2018). Protective effect of crocin against d-galactose-induced aging in mice. 8(1), 14-23.

Sadigh-Eteghad, S., Majdi, A., McCann, S. K., Mahmoudi, J., Vafaee, M. S., \& Macleod, M. R. (2017). D-galactose-induced brain ageing model: A systematic review and meta-analysis on cognitive outcomes and oxidative stress indices. PLoS ONE, 12(8), $1-13$.

Sergiev, P. V., Dontsova, O. A., \& Berezkin, G. V. (2015). Theories of aging: An everevolving field. Acta Naturae, 7(1), 9-18.

Sgarbieri, V. C., Teresa, M., \& Pacheco, B. (2017). Healthy human aging : intrinsic and environmental factors. Brazilian Journal Of Food Technology, 20, 1-23. 
Sulistyoningrum, E., \& Article, R. (2016).

Jurnal Kedokteran dan Kesehatan Indonesia D-galactose-induced animal model of male reproductive aging. 19-28.

Tolistiawaty, I., Widjaja, J., Sumolang, P. P. F., \& Octaviani. (2015). Gambaran Kesehatan pada Mencit (Mus musculus) di Instalasi Hewan Coba. Jurnal Vektro Penyakit, 8(1), 27-32.

Tosato, M., Zamboni, V., Ferrini, A., \& Cesari, M. (2007). The aging process and potential interventions to extend life expectancy (Vol. 2).

Ye, Y., Jia, R. R., Tang, L., \& Chen, F. (2014). In vivo antioxidant and anti-skin-aging activities of ethyl acetate extraction from idesia polycarpa defatted fruit residue in aging mice induced by D-galactose. Evidence-Based Complementary and Alternative Medicine, 185716, 1-12. 